\title{
Inovasi produk olahan Singkong menjadi Singkong Frozen untuk meningkatkan pendapatan masyarakat
}

\author{
Halida Sophia*, Andi Dahliaty, Titania Tjandrawati Nugroho, \& Sri Helianty \\ Universitas Riau \\ * halida.sophia@lecturer.unri.ac.id
}

\begin{abstract}
Abstrak. Kelurahan Mentangor merupakan salah satu kelurahan di Kecamatan Tenayan Raya, dengan hasil produksi singkong yang cukup melimpah. Masyarakat Mentangor pada umumnya bergerak dalam bidang perkebunan dan industri rumah tangga, yang kebanyakan pada komoditas singkong. Kebanyakan orang mengkonsumsi singkong dengan cara sederhana yaitu dengan cara direbus, digoreng, dibuat keripik, dan sebagainya. Agar tidak mengurangi citarasa jajanan tradisional tapi cepat dilirik oleh para penikmatnya, sangat memungkinkan untuk membuat inovasi olahan produk singkong menjadi singkong frozen. Kegiatan pengabdian masyarakat adalah kegiatan yang dapat membantu meningkatkan perekonomian, menambah wawasan dan keterampilan mengolah singkong melalui singkong frozen serta membantu masyarakat membentuk kelompok wanita tani (KWT). Metode yang digunakan dalam kegiatan pengabdian ini adalah dengan penyuluhan antara sosialisasi dan pelatihan serta dengan demonstrasi produksi singkong frozen. Kegiatan ini melibatkan ibu PKK dan Ibu Rumah Tangga di tiga RT nomor 01, 02, dan 03 di RW 12 Kelurahan Mentangor Kecamatan Tenayan Raya. Hasil dari kegiatan ini adalah peserta pelatihan terlihat antusias dengan materi yang disampaikan dan meningkatkan pengetahuan dan wawasan peserta tentang pengolahan singkong hingga $100 \%$.
\end{abstract}

Kata kunci: Singkong, singkong frozen, olahan singkong, frozen food

\begin{abstract}
The cassava's production arm was quite abundant. Human ratings generally revolved around plantations and in rungs industries, much of which was said in cassava commodities. Most people consume cassava in the simple way of being boiled, fried, made in chips, and so on. In order not to dull the flavor of traditional foods but to be increasingly ogled by the styrofoampurvets, it is possible to make the products of the Singkong processed innovation into cassava frozen. The public's devoted activity is to helping people improve the economy, providing added insight and skill to processing cassava through cassava frozen and helping people form a group of tapioca women (KWT). The method used in this dedicated activity is by counseling between socializing and training and by demonstrations of Singkong frozen production. This activity involves women of family welfare development and housewives in three neighborhood associations is number 01, 02, and 03 at citizens association 12, Mentangor village districts, Tenayan Raya city districts. The result of this activity is that the target public seems enthusiastic about the material presented and has increased participants' knowledge and insight on assava frocenas are $100 \%$.
\end{abstract}

Keywords: Cassava, frozen cassava, processed cassava, frozen food

To cite this article: Sophia, H., A. Dahliaty., T. T. Nugroho., \& S. Helianty. 2020. Inovasi produk olahan Singkong menjadi Singkong Frozen untuk meningkatkan pendapatan masyarakat. Unri Conference Series: Community Engagement 2: 488-493. https://doi.org/10.31258/unricsce.2.488-493

(C) 2020 Authors

Peer-review under responsibility of the organizing committee of Seminar Nasional Pemberdayaan Masyarakat 2020 


\section{PENDAHULUAN}

Kelurahan Mentangor merupakan salah satu kelurahan di Kecamatan Tenayan Raya, dengan hasil produksi singkong yang cukup melimpah. Masyarakat Mentangor pada umumnya bergerak dalam bidang perkebunan dan industri rumah tangga, yang kebanyakan pada komoditas singkong. Potensi bahan baku yang baik, dapat dijadikan peluang bisnis yang menguntungkan bagi masyarakat Kelurahan Mentagor jika diolah dan dipasarkan dengan baik. Singkong bukan hanya makanan primitif yang kebanyakan dikonsumsi oleh orang tua, tetapi anak-anak juga dapat tertarik untuk mengkonsumsinya.

Singkong atau Manihot esculenta adalah tanaman yang tergolong umbi-umbian dan banyak mengandung karbohidrat yang juga mengandung protein, Ca, B1, B2, Vitamin C dan kalori (Agato \& Batu, 2017). Singkong sangat fleksibel untuk dapat diolah menjadi produk makanan, baik secara langsung maupun menjadi bahan makanan setengah jadi (intermediate) (Ekayani, Damiati, \& Suriani, 2016). Masyarakat Kelurahan Mentangor khususnya di RW 12 berprofesi sebagai buruh, petani, guru, dan lain sebagainya. Kebanyakan ibu-ibu hanya sebagai ibu rumah tangga dan membuka usaha kecil-kecilan. Produksi singkong yang melimpah di wilayah tersebut dapat dijadikan peluang usaha untuk mengolah singkong yang lebih inovatif. Biasanya singkong hanya diolah menjadi keripik dan tape.

Kebanyakan orang mengkonsumsi singkong dengan cara yang sederhana, yakni direbus, digoreng, dibuat kolak, keripik dan lain sebagainya. Agar tidak menghilangkan cita rasa makanan khas tradisional namun semakin dilirik oleh para penikmatnya, maka dapat dibuat produk inovasi olahan singkong menjadi singkong frozen. Pengolahan singkong menjadi singkong frozen, maka masyarakat dapat mengolah singkong dengan cara yang lebih inovatif dan dapat menikmati olahan singkong yang lebih kekinian, disamping itu pengolahan singkong menjadi singkong frozen dapat meningkatkan pendapatan masyarakat.

Singkong frozen merupakan singkong yang diolah dengan cara dibekukan. Pengolahan bahan makanan setengah jadi dengan cara dibekukan dapat disimpan lebih lama dan lebih praktis. Teknologi pembekuan makanan (Frozen Food Technology) dapat menjadi solusi dalam memperpanjang umur simpan dan daya tahan suatu produk. Keunggulan dari teknik pembekuan makanan adalah kualitas makanan seperti nilai nutrisi dan sifat organoleptik tetap terjaga (Sasongko, Yuniningsih, \& Yasak, 2017). Produk pangan beku (frozen food) merupakan olahan makanan instan beku yang tahan lama dan mudah dalam penyajiannya (Santoso, Mustaniroh, \& Pranowo, 2018). Selain itu, industri frozen food merupakan bagian dari industri makanan yang tidak hanya berfokus pada kualitas rasa, tetapi ada standar-standar yang harus dipenuhi dan harus memperhatikan kehigienisan, keamanan, dan kandungan gizi yang terkandung di dalamnya.

Maka dari itu, melalui kegiatan pengabdian masyarakat diharapkan dapat memfasilitasi ibu-ibu Kelurahan Mentangor, mengolah singkong menjadi makanan yang lebih modern tanpa mengurangi rasa asli singkongnya, serta membantu masyarakat untuk meningkatkan perekonomian, memberikan tambahan wawasan dan keterampilan masyarakat dalam metode mengolah singkong menjadi singkong frozen dan membantu masyarakat membentuk Kelompok Wanita Tani (KWT) pengolah singkong.

\section{METODE PENERAPAN}

Kegiatan pengabdian ini diawali dengan survey lapangan terlebih dahulu, penyiapan alat dan bahan untuk sosialisasi dan demonstrasi pembuatan singkong frozen dan olahan singkong frozen food, serta melakukan pertemuan dengan tiga ketua RT dan RW 12 di Kelurahan Mentangor agar dapat berkoordinasi untuk mengumpulkan warga setempat.

Metode yang digunakan pada kegiatan pengabdian ini adalah dengan metode penyampaian materi dan praktek, tanya jawab, pretest dan posttest. Penyampaian materi dilakukan dalam bentuk penyuluhan yang terdiri dari sosialisasi dan pelatihan serta diiringi dengan demonstrasi pembuatan singkong frozen dan produk olahan singkong frozen. Selain itu dilakukan sosialisasi dan pelatihan pengemasan produk pangan dan pemasaran digital. Materi pelatihan disajikan lebih banyak praktek dibandingkan teori, dengan perbandingan rasio 30\% teori dan 70\% praktik. Penyampaian materi ini dilakukan dengan media powerpoint menggunakan fasilitas in focus dan alat-alat penunjang lainnya. Setelah penyampaian materi dilakukan, seluruh peserta kegiatan diberikan kesempatan untuk bertanya mengenai materi yang belum dipahami sehingga berlangsung tanya jawab antara peserta dengan tim pengabdian.

\section{HASIL DAN KETERCAPAIAN SASARAN}

Hasil singkong yang banyak biasanya banyak diolah menjadi keripik singkong dan opak. Pengolahan singkong menjadi singkong frozen, merupakan metode pengolahan singkong yang lebih inovatif, dan dapat menikmati 
olahan singkong yang lebih modern. Pengolahan singkong menjadi singkong frozen juga dapat meningkatkan pendapatan masyarakat. Secara keseluruhan, kegiatan penyuluhan ini telah dapat meningkatkan pengetahuan peserta terkait jenis singkong dan peluang usaha dari singkong, dan produk olahan singkong (stik singkong, singkong kentucky, nugget singkong, dan kroket singkong).

Hasil evaluasi proses kegiatan pengabdian dilihat dari minat atau antusias peserta kegiatan pengabdian saat pemberian materi, sedangkan evaluasi peningkatan pengetahuan dilakukan dengan membandingkan nilai pretest dan posttest mengenai pengetahuan masyarakat mengenai singkong frozen dan olahannya. Hasil dari pretest dibandingkan dengan posttest yang menunjukkan peningkatan pengetahuan ditampilkan dalam bentuk persentase yang diperoleh dari 10 peserta (masyarakat sasaran) melalui kuesioner.

Tabel 1. Persentase Perubahan Pengetahuan Peserta tentang Singkong

\begin{tabular}{ccccc}
\hline \multirow{2}{*}{$\begin{array}{c}\text { Kondisi } \\
\text { Pengetahuan }\end{array}$} & \multicolumn{2}{c}{ Jenis Singkong } & \multicolumn{2}{c}{ Peluang Usaha } \\
\cline { 2 - 5 } & Sebelum & Sesudah & Sebelum & Sesudah \\
\hline Ya tahu & 7 & 10 & 10 & 10 \\
Tidak tahu & 3 & 0 & 0 & 0 \\
\hline
\end{tabular}

\section{Persentase Perubahan \\ Pengetahuan Peserta tentang Singkong}

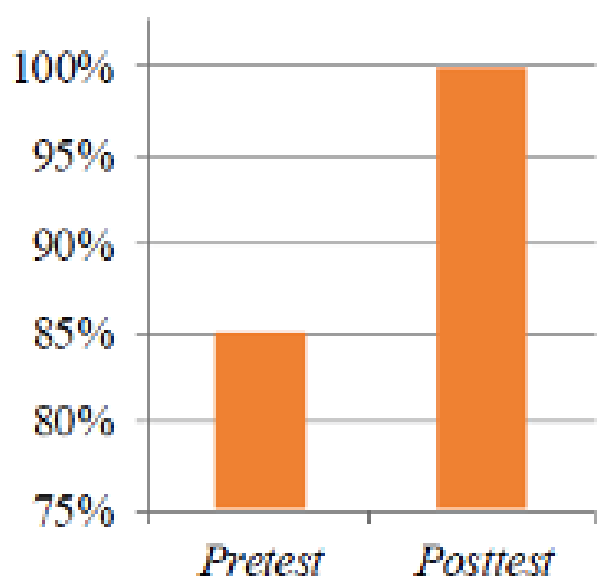

Gambar 1. Histogram Rata-rata Nilai Pretest dan Posttest tentang Singkong

Pengetahuan peserta terkait jenis singkong dan peluang usaha dari singkong (Gambar 1) meningkat. Hal ini terlihat dari peserta sebelum penyuluhan $85 \%$ sudah mengetahui tentang singkong dan meningkat menjadi $100 \%$ sepenuhnya tahu setelah sosialisasi yang diberikan tim pengabdian. Ketertarikan peserta terutama pada informasi bahwa singkong yang telah diolah menjadi produk singkong frozen dapat meningkatkan harga jualnya berkali-kali lipat, yang tentu saja hal ini dapat menjadi peluang usaha peserta dalam meningkatkan pendapatan dan kondisi ekonomi. Demikian pula pengetahuan terkait olahan singkong frozen food yang kemudian dapat dibuat produk turunannya yakni stik singkong, singkong kentucky, nugget singkong, dan kroket singkong yang menyehatkan dan berdaya jual tinggi. Hal ini menjadi inovasi baru olahan singkong menjadi nugget untuk pengganti daging ayam sebagai nugget. Sebelumnya peserta hanya mengetahui peluang usaha dari olahan singkong yang sudah sering dijumpai seperti keripik singkong dan opak. 
Tabel 2. Olahan Singkong oleh Peserta pada Umumnya

\begin{tabular}{lc}
\hline Produk Olahan & Jumlah \\
\hline Keripik dan Opak & 4 \\
Getuk & 2 \\
Perkedel & 1 \\
Tidak Mengolah & 3 \\
\hline
\end{tabular}

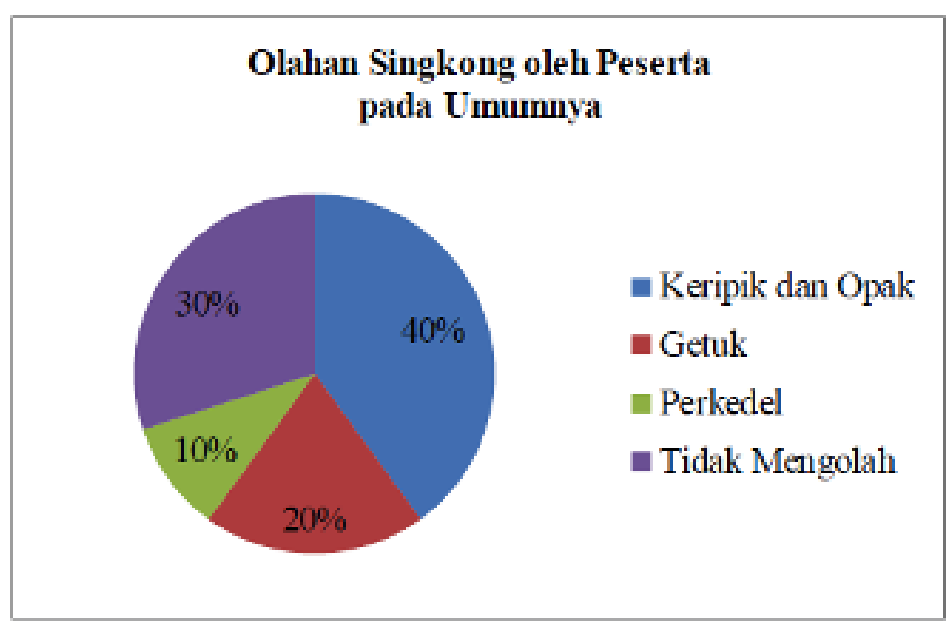

Gambar 2. Histogram Olahan Singkong Masyarakat oleh Peserta

Berdasarkan kuisioner yang telah dijawab oleh peserta (Gambar 2), diketahui bahwa 70\% peserta sudah biasa mengolah singkong menjadi beberapa produk diantaranya yakni, $40 \%$ peserta mengolah menjadi keripik dan opak, $20 \%$ mengolah menjadi getuk, dan 10\% mengolah menjadi perkedel. Disamping itu, 30\% peserta tidak mengolah singkong menjadi suatu produk. Hal tersebut menunjukkan bahwa sebagian besar peserta tidak mengetahui produk olahan singkong menjadi singkong frozen dan produk turunannya menjadi frozen food seperti stik singkong, singkong kentucky, nugget singkong, dan kroket singkong.

Tabel 3. Persentase Perubahan Pengetahuan Peserta tentang Olahan Singkong Frozen Food

\begin{tabular}{ccccccc}
\hline \multirow{2}{*}{$\begin{array}{c}\text { Tingkat } \\
\text { Mengetahui }\end{array}$} & \multicolumn{2}{c}{ Singkong Frozen } & \multicolumn{2}{c}{ Srik Singkong } & \multicolumn{2}{c}{ Singkong Kentucky } \\
\cline { 2 - 7 } & Sebelum & Sesudah & Sebelum & Sesudah & Sebelum & Sesudah \\
\hline Ya tahu & 1 & 10 & 8 & 10 & 0 & 10 \\
Tidak tahu & 9 & 0 & 2 & 0 & 10 & 0 \\
\hline Tingkat & Nugget Singkong & Kroket Singkong & & \\
Mengetahui & Sebelum & Sesudah & Sebelum & Sesudah & \\
\hline Ya tahu & 0 & 10 & 2 & 10 & & \\
Tidak tahu & 10 & 0 & 8 & 0 & & \\
\hline
\end{tabular}




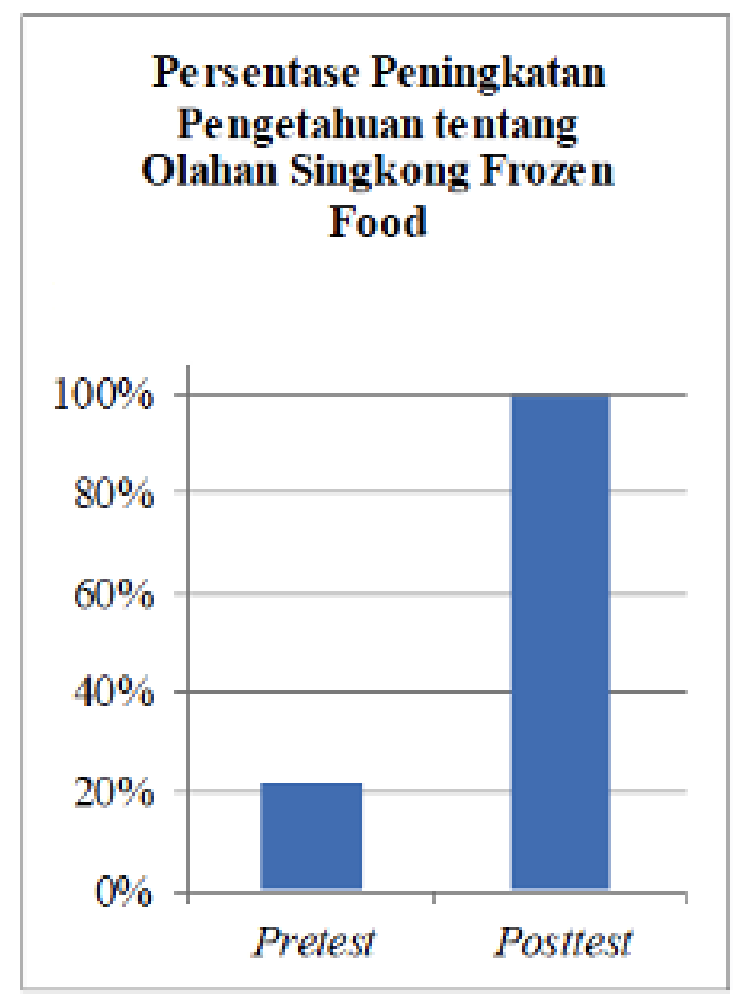

Gambar 3. Histogram Rata-rata Nilai Pretest dan Posttest tentang Olahan Singkong Frozen Food

Pengetahuan peserta terkait olahan singkong menjadi produk singkong frozen food yakni stik singkong, singkong kentucky, nugget singkong, dan kroket singkong (Gambar 3) sebelumnya masih sedikit yaitu 25\%, yang kemudian meningkat menjadi $100 \%$ sepenuhnya tahu. Peningkatan pengetahuan peserta setelah dilakukannya sosialisasi dan demonstrasi olahan singkong frozen food sebesar 75\% menandakan bahwa tim pengabdian berhasil membantu peningkatan pengetahuan peserta mengenai olahan singkong menjadi singkong frozen food. Tingginya persentase peningkatan pengetahuan tersebut juga menunjukkan tingginya minat peserta untuk mengetahui lebih dalam tentang singkong frozen. Minat tersebut dapat dilihat dari peserta membentuk kelompok wanita tani (KWT) yang bergerak dibidang pengolahan hasil pertanian untuk memproduksi olahan singkong frozen food.

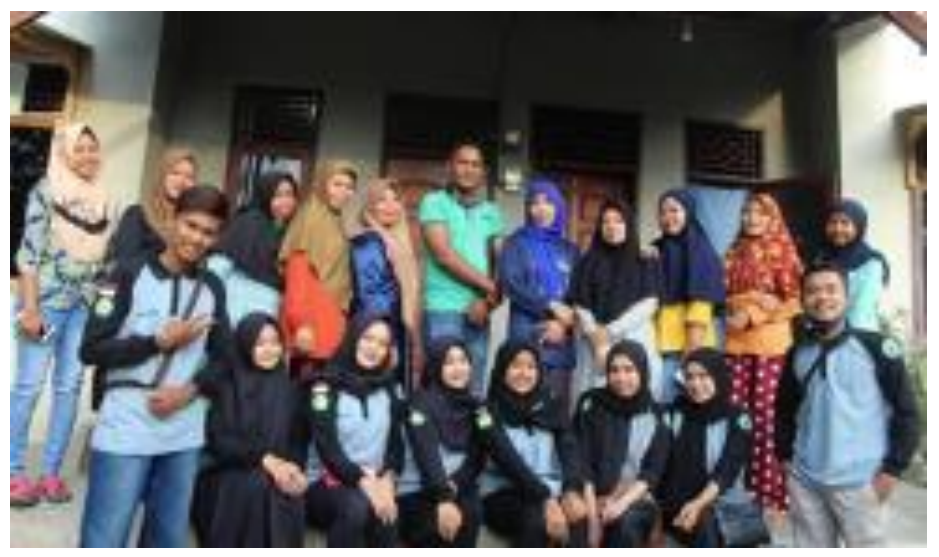

Gambar 4. Peresmian KWT (Kelompok Wanita Tani) Kembang Serumpun

Ketercapaian sasaran dan keberhasilan program pengabdian yang telah dilaksanakan ini juga dapat dilihat dari terbentuknya Kelompok Wanita Tani (KWT) di Kelurahan Mentangor, Kecamatan Tenayan Raya, Kota Pekanbaru. KWT tersebut bernama "Kembang Serumpun" (Gambar 4) yang bergerak dibidang pengolahan 
hasil pertanian untuk memproduksi dan menjual singkong frozen dan olahan singkong frozen food. KWT ini terdiri dari 15 anggota yang diketuai oleh ibu Suparmi dan dibina oleh ibu Karmila. Ketercapaian dan keberhasilan ini diharapkan dapat meningkatkan pendapat ibu-ibu rumah tangga yang ada di Kelurahan Mentangor, khususnya RW 12/RT 01.

\section{KESIMPULAN}

Kegiatan Pengabdian ini telah terlaksana dengan lancar dan masyarakat memiliki antusias yang tinggi untuk dapat mengolah singkong menjadi singkong frozen. Kegiatan sosialisasi dan pelatihan memotivasi ibu-ibu rumah tangga untuk berusaha secara berkelompok dan memiliki kesadaran bersama untuk membantu meningkatkan pendapatan keluarga. Ketercapaian sasaran dan keberhasilan program pengabdian yang telah dilaksanakan ini juga dapat dilihat dari terbentuknya Kelompok Wanita Tani (KWT) bernama "Kembang Serumpun” di Kelurahan Mentangor, Kecamatan Tenayan Raya, Kota Pekanbaru.

Masyarakat sebaiknya mengembangkan potensi pemanfaatan singkong dalam meningkatkan pendapatan masyarakat yang ada di Kelurahan Mentangor, Kecamatan Tenayan Raya, Kota Pekanbaru. Selanjutnya diperlukan kerjasama antara masyarakat dengan berbagai pihak seperti kemitraaan, dan pihak yang mendukung perkembangan pemanfaatan singkong tersebut untuk meningkatkan pendapatan masyarakat. Kegiatan ini dapat dibantu oleh BAPPEDA, dan BPOM daerah yang ada di Kelurahan Mentangor. Serta masyarakat harus lebih giat dan berusaha dalam meningkatkan kesejahteraan hidup keluarga dan mengembangkan potensi yang ada di Kelurahan Mentangor.

\section{UCAPAN TERIMA KASIH}

Penulis mengucapkan terima kasih kepada Lembaga Penelitian dan Pengabdian kepada Masyarakat Universitas Riau yang telah menyandang dana pengabdian melalui DIPA Universitas Riau tahun 2020 dengan Nomor Kontrak 870/UN.19.5.1.3/PT.01.03/2020.

\section{DAFTAR PUSTAKA}

Agato, Batu, K. L. 2017. Inovasi Olah Pangan dari Singkong di Desa Pak Bulu. 8(2), 150-154.

Ekayani, I. A. P. H., Damiati, \& Suriani, N. M. 2016). Pengusaha Produk Olahan Singkong di Kabupaten Buleleng, Bali. Seminar Nasional Pengabdian Kepada Masyarakat, (3), 149-159.

Santoso, I., Mustaniroh, S., \& Pranowo, D. 2018. Keakraban produk dan minat beli frozen food: peran pengetahuan produk, kemasan, dan lingkungan sosial. Jurnal Ilmu Keluarga dan Konsumen, 11(2), 133-144.

Sasongko, P., Yuniningsih, S., \& Yasak, E. M. 2017. Aplikasi frozen food technology untuk menurunkan tingkat kerugian produk pada kelompok perempuan buta aksara alfabet Desa Nogosari Kecamatan Rowokangkung Kabupaten Lumajang Jawa Timur. Jurnal Akses Pengabdian Indonesia, 1(1), 8-17. 